\title{
Auditing in times of social distancing: The effect of COVID-19 on auditing quality
}

\author{
Khaldoon Albitar \\ (Corresponding author) \\ Faculty of Business and Law, University of Portsmouth, \\ Portsmouth, United Kingdom \\ khaldoon.albitar@port.ac.uk
}

\begin{abstract}
Ali Meftah Gerged
Leicester Castle Business School, De Montfort University, UK and Faculty of Economics, Misurata University, Misrata, Libya ali.gerged@dmu.ac.uk
\end{abstract}

Hassan Kikhia

PricewaterhouseCoopers, Sweden.

hassan.kikhia@pwc.com

\begin{abstract}
Khaled Hussainey
Faculty of Business and Law, University of Portsmouth

Portsmouth, United Kingdom

khaled.hussainey@port.ac.uk
\end{abstract}

This paper can be cited as:

Albitar, K., Gerged, A., M., Kikhia, H., and Hussainey K. (2020). "Auditing in times of social distancing: The effect of COVID-19 on auditing quality". International Journal of Accounting and Information Management. In Press. 


\title{
Auditing in times of social distancing: The effect of COVID-19 on auditing quality
}

\begin{abstract}
Purpose: Our paper aims to discuss the theoretical impact of Covid-19 social distancing outbreak on audit quality.

Design/methodology/approach: Our paper uses a desk study method to explore the possible impact of COVID-19 crisis on five key considerations for audit quality during the pandemic. These include audit fees, going concern assessment, auditor human capital, audit procedures and audit personnel salaries.

Findings: As many believe that the COVID-19 outbreak is as yet not a financial crisis, we, on the contrary, believe that the effects of the COVID-19 pandemic would be the toughest challenge for auditors and their clients since the 2007-2008 global financial crisis. Specifically, we believe that the COVID-19 social distancing can largely affect audit fees, going concern assessment, audit human capital, audit procedures, audit personnel salaries, and audit effort, which ultimately can pose a severe impact on audit quality.

Practical implications: Due to the implementations of work-from-home strategy, audit firms are highly recommended to invest more in digital programs, including artificial intelligence, blockchain, network security, and data function development. This can help them to be more adaptable to working from home experience, which is ultimately expected to enhance the effectiveness and the flexibility of communication between auditors and their clients. Also, we recommend stock markets and other governmental bodies to provide temporary relaxations in compliance requirements to corporations. This procedure is expected to help firms that apply work-from-home strategy to report better earnings figures, which is appeared to be positively associated with audit quality.
\end{abstract}

Originality/value: To date, to the best of our knowledge, there is no academic study that explores the potential impact of the COVID-19 outbreak on audit quality. This paper, therefore, fills an important research gap in the auditing literature. In addition, our paper can be used as a base to construct a research instrument (e.g., questionnaire or interviews) to provide empirical evidence on the potential impact of COVID-19 on audit quality.

Keywords: Audit Quality, Audit Profession, Financial Reporting, Social Distancing, COVID19 Crisis.

\section{Introduction}

The rapid outbreak of the Coronavirus Disease of 2019 (COVID-19) presents an alarming health, economic, and social crises that the world is grappling with. COVID-19 pandemic has already had considerable economic and financial effects worldwide (Goodell, 2020). Crucially, these economic turbulences, coupled together with markets uncertainty, can affect investors' confidence further to firms' financial performance, and consequently might lead to various financial distresses (KPMG, 2020). The quality of audit process can significantly influence 
auditors' ability to detect material misstatements (Lenz et al., 2015) and if a firm does not ensure top quality of the audit procedure, this is expected to result in reducing shareholders' confidence in the reported earnings figures, in that way increasing investment risk and the cost of equity capital of a firm (Gerged et al., 2020). Due to the lack of investors' confidence, earnings also tend to be more volatile and present a decreasing pattern during the economic turbulence period (Kousenidis et al., 2013; Arthur et al., 2015). As companies in different countries around the world such as the UK and India approach their fiscal year-end, there is an urgent need to evaluate the effects of the COVID-19 outbreak on their financial reports, which are considered as the main source of information for different groups of stakeholders and the key means for the decision-making process (Shahzad et al., 2018). Auditors, as such, are facing unprecedented practical challenges in many areas, and many companies may bankrupt or start to manipulate their earnings figures during this exceptional situation. Given the importance of auditing for ensuring the quality of financial statements which enhance investors' decision making and integrity of financial markets (Gerged et al., 2020; Tarek et al., 2017; Shahzad et al., 2018), the Financial Reporting Council (FRC) has issued in March 2020 a specific notice related to the impact of the COVID-19 outbreak on audit quality that provides a guide for auditors on the matters that should be considered in relation to the impact of social distancing measures on audit quality (Financial Reporting Council, 2020).

Financial Reporting Council (2020) has mentioned that: "In this period auditors will need to consider the impact of COVID-19 on

- The auditor's risk assessment, and whether it needs to be revised;

- How the auditor gathers sufficient, appropriate audit evidence, recognising that the planned audit approach may need to change, and alternative procedures developed, particularly ingroup audit engagements. The auditor must be able to gather the necessary evidence to be able to report or consider modifying their audit opinion;

- How the group auditor proposes to review the work of component auditors to meet the requirements in standards, including considering whether alternative procedures can be used: for example, where travel is restricted;

- The auditor's assessment of going concern and the prospects of an audited company, given that uncertainty about the global economy and the immediate outlook for many companies has increased;

- The adequacy of disclosures made by management about the impact on the company of COVID-19, so that users of the financial statements are properly informed, and the 
company's prospects and how they might be affected are described, recognising the high degree of uncertainty; and

- The need for the auditor to reassess key aspects of their audit as a result of the fast-changing situation, recognising that this assessment will take place right up to the point of signing the auditor's report, and may need the provision of further evidence and information by management. Where the current circumstances have had a significant impact on the delivery of the audit, the auditor will need to consider how to explain this in their report, for example, by reporting this as a key audit matter."

The above-mentioned points suggested by the Financial Reporting Council (2020) motivates us to a desk study method to examine the impact of COVID-19 on audit quality. Our paper tries to theoretically answer the following research question: How can the COVID-19 outbreak affect the quality of the audit process during the pandemic?

Although a very limited number of recently published studies have been undertaken to highlight the magnificent economic and social impacts of the COVID-19 pandemic such as Goodell (2020), so far, a study exploring the possible influence of the COVID-19 outbreak on audit quality does not exist. Our study, therefore, aims to address this research gap in auditing literature and extends the existing body of prior studies by exploring the possible effects of the COVID-19 outbreak on audit quality. Specifically, we review the potential impact of this pandemic on five aspects related to audit quality: audit fees, going concern assessment, auditor human capital, audit procedures and audit personnel salaries. In doing so, our paper provides a systematic picture for future researchers, investors and auditors about the possible effects of social distancing on audit quality. In this case, our study contributes to the existing literature by conceptualising the relationship between COVID-19 and audit quality. Future research could complement our study by constructing a questionnaire survey or an interview schedule to empirically examine the COVID 19-audit quality nexus.

The paper is structured as follows. Section 2 discusses the impact of COVID-19 on audit fees. The impact of COVID-19 on going concern assessment is reviewed in Section 3, while its impact on audit procedures is explained in Section 4. In Section 5, we discuss the potential impact of COVID-19 audit human capital, while in Section 6, we discuss its potential impact on audit staff salaries. Section 7 is our conclusion.

\section{COVID-19 and Audit fees}

The changing economic conditions are challenging for audit companies and their clients as these changes will affect the company's liquidity, risk and performance, which will ultimately 
affect audit fees (Chen et al., 2019). More specifically, there is a higher risk that the company may violate the conditions stipulated in the debt contract, and some companies, therefore, may go bankrupt. Higher risk levels and growing concerns of creditors will force auditors to adopt broader audit procedures and invest more in audit work when evaluating firms' going concern assumptions (Ghosh and Pawlewicz, 2009; Noh et al., 2017; Zhang and Huang, 2013; Chen et al., 2019). During this pandemic, the growing demand for assurance and the increased risk of auditor litigation would increase the auditor's effort and working hours (Karim and Zijl, 2013; Yuen et al., 2013). Lowballing does not impair audit quality instead it is a rational and competitive response to the expectation of incumbency's technological advantages and initial fee reductions are sunk costs in the future, and therefore, will not affect auditor's independence and audit quality (Deangelo, 1981). Yet, this could be correct during a normal situation. Xu et al. (2013) studied audit fees in Australia and reported an increase in audit fees during the financial crisis. The authors argue that this is because of the increase in client business risk, which caused additional audit effort. Nonetheless, some previous studies have suggested that during the global financial crisis, companies negotiate a lower price for audit services (Krishnan and Zhang, 2014; Alexeyeva and Svanström, 2015; Karim et al., 2013; Bozec and Dia, 2017; Chen et al., 2018; Chen et al., 2019). As social distancing and work-from-home became a 'new normal' during the Covid-19 pandemic, this seems to increase the working hours and auditor's effort, although companies (clients) are likely to start asking for lowballing of audit fees (Chen et al., 2019). In this case, auditors may reduce their efforts in order to minimise the loss on the engagement; thus, undoubtedly owing to this exogenous shock of COVID-19, auditors may be under pressure from clients to cut audit fees during the crisis. This expected decline in audit fees appears to be largely affecting audit quality during the COVID19 outbreak.

\section{COVID-19 and going concern assessment}

In the current COVID-19 pandemic, as many companies have implemented closures and reduced the level of sales, it could be difficult for auditors to assess whether the current situation cast critical doubts on the company's ability to continue as a going concern, or in extreme situations whether the going concern basis itself is still appropriate as a basis for the preparation for corporate financial statements (KPMG, 2020). In addition, there are many questions as to whether companies and auditors need additional time to fully consider the impact of this epidemic (PWC, 2020). In previous research on auditor's response to the financial crisis, $\mathrm{Xu}$ et al., (2013) indicate that auditors have taken conservative measures during 
the global financial crisis by not only increasing their propensity to issue going-concern opinions but also by expanding the audit effort. This is to protect themselves from higher risk exposure during the global financial crisis. However, Mareque et al. (2017) find that the percentage of reports issued with going concern qualifications before and during the crisis were similar.

It is essential that auditors are sceptical when conducting the ongoing concern assessment, and that their working documents should show evidence of such scepticism. This also raises the challenge of risking internal control operations due to work-from-home strategy (PWC, 2020). In addition, it is essential for auditors to spend sufficient time on the assessment of going concern and accept that it will take a longer time than usual for most clients. This work may be more sophisticated during the outbreak of COVID-19 as the uncertainty level is higher, which implies the crucial necessity to use the appropriate level of staff and to provide the appropriate and sufficient support to auditors (KPMG, 2020). Due to the rapid changes in the situation, it is also important for auditors to ensure that the subsequent review of events continues until signing the audit report (PWC, 2020).

During the COVID-19 pandemic, the most common reason for issuing audit reports with uncertainties is because of doubts about the continuity of the company. These uncertainties are attributable to the lack of liquidity and the deterioration of economic development of company activities as well as the economic crisis that we are currently suffering caused by COVID-19 in most sectors (KPMG, 2020). All of these circumstances have led many companies to have higher business risks. Therefore, once again, because of this pandemic, we should expect it to have a considerable impact on the completion of the going concern assessment, which seems to be associated with audit quality (Salehi et al., 2020).

\section{COVID-19 and audit procedures}

Another issue that can be affected by the current pandemic is the performance of analytical procedures that is representative of an integral part of the audit process (Messier et al., 2013). Analytical procedures are used for audit planning, fieldwork, and audit conclusion, evaluation and reporting stages (Trompeter \& Wright 2010; Messier et al., 2013; Noh et al., 2017). During the COVID-19 pandemic, because many companies could go bankrupt or manipulate their reported earnings during this crisis, auditors have to increase the use of analytical procedures due to the fact that analytical procedures have the lowest cost and are relatively easy to calculate (Rose et al., 2020). Analytical audit procedures are desirable in terms of cost and can be used 
to guide auditors and equip them with relevant pieces of evidence to support their conclusions (Calderon and Green, 1994). These procedures usually involve a diagnostic process that determines the cause of unexpected fluctuations in account balances or the risk of major misstatement due to fraud during the audit plan (Rose et al., 2017; Rose et al., 2020).

There is a potential threat to audit quality associated with generating many explanations when considering fraud risks (Rose et al., 2020). Given that, generating many alternative explanations does not consistently activate critical thinking and may even have the opposite effect (Hirt et al. 2004; Kadous et al. 2006). In addition, auditors will try to rely more on analysis procedures that help them to have a comprehensive understanding of the companies' financial position, thereby reducing the number of detailed tests that are so expensive and take a long time taking into consideration that most of the communications during the COVID-19 pandemic are by emails (KPMG, 2020).

The quality of audit evidence is very important to ensure that the auditor's conclusions are correct. If the reported information is not very strong or the quality is low, then the audit risk of making a wrong audit opinion is high (Rose et al., 2017). The quality of audit evidence mainly depends on the form and source of the evidence. Due to COVID-19, auditors are more likely to rely on evidence from external sources such as evidence obtained directly from external parties such as customers, suppliers, or banks, which are more reliable than those obtained from clients (PWC, 2020). For example, the account receivable confirmation obtained from client's customers is more reliable than the records prepared by clients. However, the level of reliability of evidence obtained from clients is determined by the reliability of client internal control (Rose et al., 2020). On the other side, the COVID-19 pandemic has decreased the use of the original forms, for example, original invoices that used to support the payments transactions that are more reliable than the copy invoices sent by email; thus the working-fromhome strategy would affect the sufficiency and reliability of audit evidence and consequently might affect audit quality (KPMG, 2020).

\section{COVID-19 and audit human capital}

The FRC believes that skills, personal qualities and training of audit partners and employees are important factors in determining auditor quality. Such a practice would aim to enhance employees' expertise and competency and thus improve audit quality. In this regard, Francis (2011) state that the training of auditors is located at the heart of the audit profession. Consistent with this view, a body of previous studies pointed out that the investment in human capital can 
improve the audit quality (Cheng et al., 2009; Aldhizer et al., 1995; Liu, 1997; Chen et al., 2008; Antonio and Rodrigues, 2016). Given that, audit human capital appeared to have great potential to play a critical role in the audit process and primarily affect the quality of this process.

The professional knowledge of auditors has an indelible connection with individuals, and it can improve learning and performance during the audit process (Bianchi et al., 2019). Expertise and professional knowledge can be obtained through indirect experiences, such as training, workshops, and direct experience, such as more interaction with customers in specific industries (Lennox and $\mathrm{Wu}, 2018$ ). Relatedly, Chen et al. (2008) found that professional experience gained during on-the-job training can substantially improve audit performance and therefore, audit quality.

Although audit firms have a tendency to arrange monthly training sessions, workshops and similar professional development activities for employees, the COVID-19 outbreak has enforced all audit companies to cancel all their monthly training, workshops and other professional development programmes for their auditors at all levels (Deloitte, 2020). This is following the new plan of cutting costs and the social distancing caused by the COVID-19 pandemic. These effects of the social distancing strategy expected; therefore, to be directly reflected on the efficiency and the ability of auditor and may have a negative impact on audit quality. In addition, there is a possibility of personnel loss due to illness or quarantine, which collectively might affect the performance of audit firms, their efficiency and audit quality.

\section{COVID-19 and audit staff salaries}

In recent years, the issue of auditors 'salaries has become an important issue due to the major changes in the public accounting industry that have resulted in more complexity and increasing responsibilities and workloads on auditors (Persellin et al. 2018). Although the salary of the auditor may be significantly attributed to audit quality, a few studies have considered the relationship between the salary of the auditor and audit quality, which is mainly due to data constraints.

Since the beginning of the COVID-19 pandemic, we started to hear about extraordinary measures to help workers and companies throughout the period of the COVID-19 outbreak. Some companies started to talk about pay cuts or offering unpaid leave (Deloitte, 2020). However, the relation between audit personnel' salary and audit quality is as yet unclear. The efficiency wage theories imply that higher wages should improve audit personnel productivity 
by either motivating greater effort or attracting higher quality audit personnel (Hoopes et al., 2018). Therefore, it is expected that the COVID-19 pandemic would affect audit personnel salaries, which in return might negatively affect the performance of audit personnel as they would have few motivations to do their duties in the most efficient and effective manner. Thus, we argue that any reduction in the salaries of audit personnel can have a potentially negative effect on audit quality.

\section{Conclusions}

As many believe that the COVID-19 outbreak is as yet not a financial crisis, and it has a shortlived impact comparing with the effects of the global financial crisis, we on the contrary, on the other hand, believe that there is a huge risk that this health crisis could degenerate into something worse and the effect of the COVID-19 pandemic would be the toughest challenge for auditors and their clients since the 2007-2008 global financial crisis. This is a brief paper that aims to theoretically discuss how audit quality can be affected by the COVID-19 pandemic, which provides suggestions for future researchers and auditors following this exogenous shock. Theoretically, we expect, as a result of this pandemic, to see a decline in audit fees, challenges in the completion of the going concern assessment, low-levels of reliability and sufficiency of audit evidence, huge possibilities of personnel loss due to illness or quarantine, and reductions in the salaries of audit personnel, which in turn expected to influence the quality of audit process.

Our study has several policy and practitioner implications. As a result of social distancing and the implementations of work-from-home strategy, audit firms are highly recommended to invest more in digital programs, including artificial intelligence, blockchain, network security, and data function development as that would help them to be more adaptable to working from home experience, which is ultimately expected to enhance the effectiveness and the flexibility of communication between auditors and their clients. Given the global implementations of the lockdown strategy that is believed to increase working hours and efforts for auditors, we recommend stock markets and other governmental bodies to provide temporary relaxations in compliance requirements to corporations. For example, stock markets can extend the timelines for filing of financial results for years ended 31 March 2020/21. This procedure is expected to help firms that apply work-from-home strategy to report better earnings figures, which is appeared to be positively associated with audit quality. Also, tax authorities should extend the 
deadline for tax payment, self-assessment tax return and/or deferral of tax payments and remitting penalties and interest; tax authorities can also apply special measures to taxpayers that are the most affected by COVID-19 to help them mitigate the impact of this crisis.

To date, a study exploring the potential impact of the COVID-19 outbreak on audit quality is virtually non-existent. This study, therefore, provides a systematic picture for future researchers, auditors and corporate managers about the significant impact that the COVID-19 outbreak has already had on international financial markets and the economies of affected countries, which is largely expected to affect firms' financial performance, the reported earnings figures, and hence the quality of audit. Additionally, our study can be employed as a base to construct a research instrument (e.g., questionnaire or interviews) to provide empirical evidence on the potential impact of COVID-19 on audit quality. One of our research limitations is that our paper does not include any empirical examination of the possible effects of the COVID-19 outbreak on audit quality. Future research could complement our study by providing empirical evidence on the impact of COVID-19 crisis on audit fees, going concern assessment, audit human capital, audit procedures, audit personnel salaries, and audit effort? Further research could examine the policy questions of how (and why) this outbreak affect audit quality. No doubt, these questions have to be investigated in the future because of their practical implications. Finally, we conclude that COVID-19 is more likely to have a negative impact on audit quality. Further research could examine the potential consequences of reducing audit quality during the COVID-19 pandemic on the quality of financial statements as well as the quality and quantity of narrative reporting. In addition, COVID-19 poses significant challenges for corporate social responsibility (CSR) activities. Further research could attempt to answer the following questions: Should firms withdraw, maintain or expand their CSR activities. To what extent do the CSR disclosure quality and quantity improve during the pandemic? What are the main drivers for CSR activities during the pandemic? Does the audit quality matter? Finally, Albitar et al. (2020) provide evidence that corporate governance moderates the relation between Environmental, Social and Governance (ESG) and firm performance. Further research could also investigate if audit quality moderate or mediate the relation between CSR or ESG disclosure and firm performance during the pandemic.

\section{Reference:}


Albitar, K, Hussainey, K., Kolade, N, and Gerged, A. (2020). ESG disclosure and firm performance before and after IR: The moderating role of governance mechanisms. International Journal of Accounting \& Information Management, 28 (3): 429-444.

Aldhizer, G.R., Miller, J.R. and Moraglio, J.E. (1995), “Common attributes of quality audits", Journal of Accountancy, Vol. 179, pp. 61-8.

Alexeyeva, I. and Svanström, T. (2015), "The impact of the global financial crisis on audit and non-audit fees: Evidence from Sweden", Managerial Auditing Journal, Vol. 30 No. 4/5, pp. 302-32

Antonio, S. and Rodrigues, R. (2016). Human capital and performance in young audit firms. Journal of Business Research, Vol. 69, pp. 5354-59.

Arthur, N., Tang, Q., \& Lin, Z. (2015). Corporate accruals quality during the 2008-2010 Global Financial Crisis. Journal of International Accounting, Auditing and Taxation, Vol. 25, pp. $1-15$.

Bianchi, P., Carrera, N., \& Trombetta, M. (2019). The Effects of Auditor Social and Human Capital on Auditor Compensation: Evidence from the Italian Small Audit Firm Market. European Accounting Review. In press.

Bozec, R. and Dia, M. (2017), "Monitoring function of the board and audit fees: contingent upon ownership concentration", International Journal of Accounting \& Information Management, Vol. 25 No. 1, pp. 70-90.

Chen, H., Hua, S., Liu, Z. and Zhang, M. (2019), "Audit fees, perceived audit risk, and the financial crisis of 2008", Asian Review of Accounting, Vol. 27 No. 1, pp. 97-111.

Chen, L., Krishnan, G.V., \& Yu, W. (2018). "The relation between audit fee cuts during the global financial crisis and earnings quality and audit quality". Advances in Accounting, Vol. 43, pp. 14-31.

Chen, Y.S., Chang, B.G. and Lee, C.C. (2008), "The association between continuing professional education and financial performance of public accounting firms", International Journal of Human Resource Management, Vol. 19 No. 9, pp. 1720 37.

Cheng, Y., Liu, Y. and Chien, C. (2009), "The association between auditor quality and human capital", Managerial Auditing Journal, Vol. 24 No. 6, pp. 523-541.

DeAngelo, L. (1981). Auditor independence, 'low balling', and disclosure regulation, Journal of Accounting and Economics, Aug., pp. 113-127.

Deloite. (2020). Potential implications of COVID-19 for the insurance sector. Accessed on the $27^{\text {th }}$ of April 2020 at https://www2.deloitte.com/uk/en/insights/economy/covid19/impact-of-covid-19-on-insurers.html

Francis, J. R. (2011). "A Framework for Understanding and Researching Audit Quality". Auditing: A Journal of Practice \& Theory, Vol. 30 No. 2, pp. 125-152.

Financial Reporting Council (2020). Guidance on audit issues arising from the Covid-19 (Coronavirus) pandemic. Available at https://www.frc.org.uk/news/march-2020(1)/guidance-on-audit-issues-arising-from-the-COVID-19. (access on 22 August 2020)

Gerged, A. M., Mahamat, B. B., \& Elmghaamez, I. K. (2020). Did corporate governance 
compliance have an impact on auditor selection and quality? Evidence from FTSE 350. International Journal of Disclosure and Governance, Vol. 17 No.2, pp.15-60.

Ghosh, A. and Pawlewicz, R. (2009), "The impact of regulation on auditor fees: evidence from the Sarbanes-Oxley Act”, Auditing: A Journal of Practice and Theory, Vol. 28, pp. 171197.

Goodell W. J. (2020). "COVID-19 and finance: Agendas for future research". Finance Research Letters. In press.

Hirt, E., F. Kardes, and K. Markman. (2004). “Activating a mental simulation mindset through the generation of alternatives: Implications for debiasing in related and unrelated domains". Journal of Experimental Social Psychology, Vol. 40 No. 3, pp. 374-383.

Hoopes, J.L., Merkley, K.J., Pacelli, J. (2018). "Audit personnel salaries and audit quality”. Review of Accounting Studies, Vol. 23, pp. 1096-1136.

Kadous, K., S. Krische, and L. Sedor. (2006). "Using counter-explanation to limit analysts' forecast optimism”. The Accounting Review, Vol. 81 No. 2, pp. 377-397.

Karim, A.K.M.W. and Zijl, T.V. (2013), "Efficiency and opportunism in auditor quality choice in emerging audit services markets: the case of Bangladesh", International Journal of Accounting and Information Management, Vol. 21 No. 3, pp. 241-256.

Knechel, W. R., L. Niemi, and M. Zerni. (2013). "Empirical Evidence on the Implicit Determinants of Compensation in Big 4 Audit Partnerships". Journal of Accounting Research, Vol. 51 No. 2, pp. 349-387.

Kousenidis, D.V., Ladas, A.C., \& Negakis, C.I. (2013). "The effects of the European debt crisis on earnings quality”. International Review of Financial Analysis, Vol. 30, pp. 351-362.

KPMG. (2020). "COVID-19: Potential impact on financial reporting". Accessed on the $27^{\text {th }}$ of April 2020 at https://home.kpmg/xx/en/home/insights/2020/03/covid-19-financialreporting-resource-centre.html

Krishnan, G.V. and Zhang, Y. (2014), "Is there a relation between audit fee cuts during the global financial crisis and banks' financial reporting quality?", Journal of Accounting and Public Policy, Vol. 33 No. 3, pp. 279-300.

Lennox, C. S., and Wu, X. (2018). "A review of the archival literature on audit partners. Accounting Horizons”, Vol. 32 No. 2, pp. 1-35.

Lenz, R., and U. Hahn. (2015). “A synthesis of empirical internal audit effectiveness literature pointing to new research opportunities". Managerial Auditing Journal, Vol. 30 No. 1, pp. 5-33.

Malcomson, J. M. (1981). "Unemployment and the efficiency wage hypothesis". The Economic Journal, Vol. 91 No. 364, pp. 848-866.

Mareque, M., López-Corrales, F., \& Pedrosa, A. (2017). “Audit reporting for going concern in Spain during the global financial crisis". Economic Research Ekonomska Istraživanja, Vol. 30 No. 1, pp.154-183.

Messier, W.F., Simon, C.A. \& Smith, J.L. (2013). "Two decades of behavioural research on analytical procedures: what have we learned?" Auditing: A Journal of Practice \& Theory, Vol. 32 No. 1, pp. 139-181. 
Noh, M., Park, H. and Cho, M. (2017), "The effect of the dependence on the work of other auditors on error in analysts' earnings forecasts", International Journal of Accounting \& Information Management, Vol. 25 No. 1, pp. 110-136.

Persellin, J., Schmidt, J.J., Vandervelde, S.D., \& Wilkins, M. (2018). “Auditor perceptions of audit workloads, audit quality, and job satisfaction". S.S.R.N. Electronic Journal. DOI: $10.2139 / \mathrm{ssrn} .2534492$

PWC. (2020). "COVID-19: Responding to the business impacts of Coronavirus". Accessed on the $27^{\text {th }}$ of April 2020 at https://www.pwc.com/gx/en/issues/crisis-solutions/covid19.html

Rose, A. M., Rose, J. M., Suh, I., \& Thibodeau, J. C. (2019). “Analytical Procedures: Are More Good Ideas Always Better for Audit Quality?". Behavioral Research in Accounting, Vol. 32, No. 1, pp. 37-49.

Rose, A. M., Rose, J. M., Suh, I., \& Thibodeau, J. C. (2019). “Analytical Procedures: Are More Good Ideas Always Better for Audit Quality?", Behavioral Research in Accounting. In Press.

Rose, A., J. Rose, K. Sanderson, and J. Thibodeau. (2017). "When should audit firms introduce analyses of Big Data into the audit process?", Journal of Information Systems, Vol. 31 No. 3, pp. 81-99.

Salehi, M., Mahmoudi, M. R. F., \& Gah, A. D. (2020). A meta-analysis approach for determinants of effective factors on audit quality. Journal of Accounting in Emerging Economies. Vol. 9 No. 2, pp: 287-312.

Shahzad, K., Pouw, T., Rubbaniy, G., \& El-Temtamy, O. (2018). "Audit quality during the global financial crisis: The investors' perspective", Research in International Business and Finance, Vol. 45, pp. 94-105.

Tarek, M., Mohamed, E.K., Hussain, M.M. and Basuony, M.A. (2017), "The implication of information technology on the audit profession in developing country: extent of use and perceived importance", International Journal of Accounting and Information Management, Vol. 25 No. 2, pp. 237-255.

Trompeter, G. \& Wright, A. (2010). "The world has changed: have analytical procedure practices?" Contemporary Accounting Research, Vol. 27 No. 2, pp. 669-700.

Xu, Y., Carsona, E., Fargherb, N. and Jiang, L. (2013), "Responses by Australian auditors to the global financial crisis", Accounting and Finance, Vol. 53 No. 1, pp. 303-338.

Yuen, D.C.Y., Law, P.K.F., Lu, C. and Guan, J.Q. (2013), "Dysfunctional auditing behaviour: empirical evidence on auditors' behaviour in Macau", International Journal of Accounting \& Information Management, Vol. 21 No. 3, pp. 209-226.

Zhang, T. and Huang, J. (2013), "The risk premium of audit fee: evidence from the 2008 financial crisis", China Journal of Accounting Studies, Vol. 1 No. 1, pp. 47-61. 